\title{
A Comparative Study on the Delisting Ratings of Firms from the UN Global Compact in the International Management Environment
}

\author{
Kanako Negishi \\ Business Administration, National Institute of Technology, Ube College, \\ Tokiwadai, Ube City, Yamaguchi Pref., 755-8555, Japan \\ E-mail: negishi@ube-k.ac.jp \\ www.ube-k.ac.jp/en/
}

\begin{abstract}
This study clarifies unique characteristics of Japanese manufacturing firms in the international business management environment using the United Nations Global Compact delisting ratio through a comparative study on Japan, China, Spain, and the US. Analyzing the number of countries and delisting ratios of the firms by size and sector, I find a trend that Japanese firms have a low delisting ratio than firms in other countries and that SMEs have a higher delisting ratio than larger companies.
\end{abstract}

Keywords: United Nations Global Compact delisting ratio, Japanese manufacturing industry, code of conduct, voluntary initiative

\section{Introduction}

Firms' international business environment has changed. In particular, this has included a transition in the area of sustainability. After the 1990s, many guidelines and principles for firms were developed by public institutions and non-governmental organizations, such as the United Nations Global Compact (GC), Global Reporting Initiative (GRI), and Integrated Reporting (IR) to improve international firms' activities. For example, over 9,000 firms participated in the GC.*

Although some guidelines and principles are not legally binding, such as the GC, there is a recent trend toward integration to achieve comparability in the international management of sustainability among firms. ${ }^{1}$ Such integration binds firms' management as a de facto standard. While GRI does not have legal power to force firms to use GRI guidelines; such guidelines are now the most common way to report a firm's sustainability worldwide. ${ }^{2}$

Sustainability is a very important aspect of a firm's international management, and participation in a global initiative such as the GC is one way to demonstrate firms' sustainability effects to their stakeholders. Previous research tends to focus on the positive aspects of participation in voluntary initiatives, such as increased participation and progress in the labor working environment in the GC. However, not all firms achieve sustainable management with such international actions; indeed, some firms are expelled from the GC at fixed intervals. Therefore, there is also a need to clarify the tendency for firms to fail and the reasons why they do.

This study examines the manufacturing sector, which receives among the greatest amount of foreign direct investment (FDI) in Japan, through a comparative study

${ }^{*}$ United Nations Global Compact homepage, https://www.unglobalcompact.org/what-is-gc/participants (25 Nov. 2016 last access) 
of Japanese, Chinese, Spanish, and US firms by size, sector, and country.

\section{Literature Review and Research Object}

Ref.3 notes that the past few years have seen a rapid increase in pressure regarding accountability on companies. The situation has become rather complex in recent years, especially for multinational enterprises that face myriad requests from shareholders and other stakeholders in various markets with often differing regulations and governance systems.

To respond to such pressure from stakeholders, firms can participate in a voluntary initiative and adopt principles and/or guidelines. Not only multinationals but also SMEs do so because, in the view of many contractors, certification is critical for firms to secure foreign contracts in the first place, even though compliance does not necessarily lead to a greater number of committed buyers or any additional business. ${ }^{4}$

As noted above, not all firms successfully engage in and manage such voluntary initiatives. Although there is criticism about firms' participation in the GC, there is a lack of information explaining "why some of the companies that join voluntary social and environmental initiatives ultimately fail to live up to the requirement. ${ }^{5}$ In this regard, Ref.5 examines firm delisting by country, size, sector, international economic independence, quality of governance institutions, and share of FDI per capita.

The emerging literature nevertheless lacks such information on the practices of Japanese firms. Most of the guidelines and principles have been developed in advanced Western countries, as the concepts of sustainability and corporate social responsibility (CSR) have historically been developed in such countries. However, some of the guidelines and principles originated in Japan and have been adopted by Japanese firms. Yet, none of these guidelines and principles have spread globally as with GRI, whose head office is in the Netherlands.

To clarify firms' tendency to fail in this regard and the reasons for such failure in the GC, this article examines the number of delisted firms by country using the data on delisting companies from Ref.5 for April 14, 2008 and Ultimo for 2004. Therefore, this paper renews and expands the data to include the period from March 23, 2008, to February 09, 2018, by using the delisted database. To show the details of the industry index, the study focuses on the manufacturing industry.

\section{Method and Dataset}

The analysis used data from the GC database of participants and delisted participants. Firms are expelled if they fail to submit their reports to the $\mathrm{GC}$ at least once per year. The first date of delisting from the GC is March 27, 2002.

According to the GC, a company is defined as a firm with more than 250 employees, while an SME has fewer than 250 employees but more than ten employees.

The target countries are Japan, Spain, China, and the US. As Spain ranks at the top of GC participants by country, I selected countries based on the ranking in each region.

This study focuses on the manufacturing sector. According to the GC, this sector includes automobile and parts, construction and materials, electronic and electrical equipment, healthcare equipment and services, household goods and home construction, industrial engineering, personal goods, and technology hardware and equipment.

\section{Results and Findings}

Figure 1 shows the number of delisted firms by country, which has changed since previous research was conducted. Ref.5 reported that the Philippines has the most delistings (98), followed by France (71 delistings), Spain (48), Brazil, Bulgaria, India, Turkey, the US, Cameroon, and China. The landscape of delisted firms by country has changed substantially, with the Philippines, Bulgaria, Turkey, and Cameroon no longer in the top ten countries, and Mexico, Argentina, and Myanmar now in the top ten.

According to the UN annual report, the regional distribution of delistings closely resembles that of new joiners. This trend is also generally demonstrated quantitatively: Spain has the most participants, followed by France, Brazil, and Mexico.

Table 1 shows the delisting ratios of countries by size and sector. 


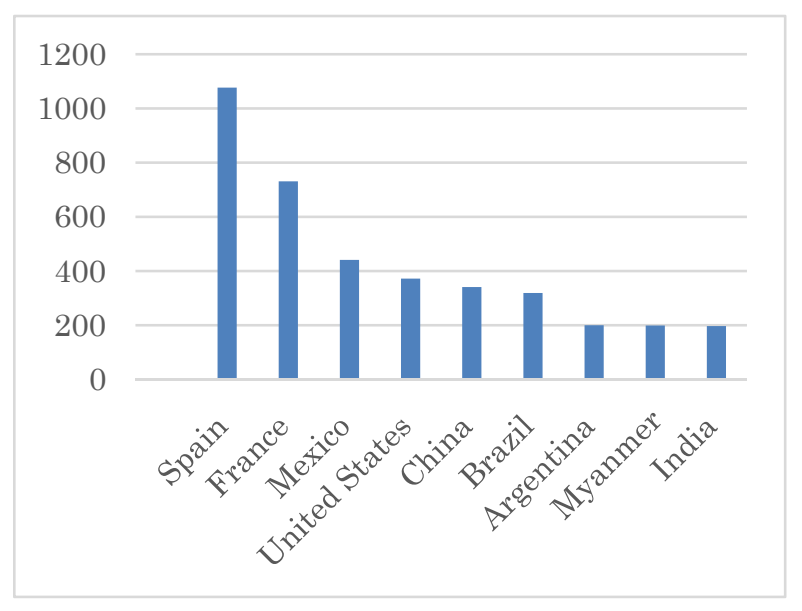

Fig. 1. Number of delisted firms by country.

\subsection{Size}

Actions undertaken by large firms are more visible, so firm size is an important factor for analysis. ${ }^{6}$ The ratio of Chinese SMEs is relatively high. However, the overall trend is applicable to all countries, and it has not changed from that in previous research.

By way of exception, seven parts of the table show higher ratios for larger companies than for SMEs. However, except for the company delisting ratio for general industrials in China and the ratio for personal

\subsection{Sector}

In the manufacturing industry, the automobile and parts and personal goods sectors have relatively lower ratios than the other sectors. However, there is no clear difference between sectors.

\section{Considerations and Further Research}

From this comparative study on the manufacturing industry, we have clarified that Japanese companies' delisting ratios are overwhelmingly the lowest among the examined countries. The number of Japanese firms participating in the GC is not small. Moreover, once they participate, they do not delist, unlike firms in other countries. However, Ref.7 notes that there are many more withdrawals among Japanese firms from the GC than among firms from other countries. This is a unique characteristic to Japanese firms. Vogel notes that Japanese consumers do not request greater responsibility among firms than consumers in Europe and the US do. Indeed, firms in Western countries sometimes must maintain high-quality sustainable management because of high consumer pressure. However, given the low ratio of delisting among Japanese firms shown in the results, it is necessary to explore the reasons why.

Second, the results show that the ratio is higher for SMEs than for larger companies. Ref.8 noted that multinationals face growing pressure to account for social, environmental, and ethical problems occurring in

Table 1. Delisting ratio of Spanish, Chinese, Japanese, and US firms by size and sector

\begin{tabular}{|c|c|c|c|c|c|c|c|c|}
\hline \multirow[b]{2}{*}{ Sector } & \multicolumn{2}{|c|}{ Spain } & \multicolumn{2}{|c|}{ China } & \multicolumn{2}{|c|}{ Japan } & \multicolumn{2}{|c|}{ US } \\
\hline & $\begin{array}{l}\text { Rating of } \\
\text { larger } \\
\text { company } \\
\text { delisting }\end{array}$ & $\begin{array}{l}\text { Rating of } \\
\text { SME } \\
\text { delisting }\end{array}$ & $\begin{array}{l}\text { Rating of } \\
\text { larger } \\
\text { company } \\
\text { delisting }\end{array}$ & $\begin{array}{l}\text { Rating of } \\
\text { SME } \\
\text { delisting }\end{array}$ & $\begin{array}{l}\text { Rating of } \\
\text { larger } \\
\text { company } \\
\text { delisting }\end{array}$ & $\begin{array}{l}\text { Rating of } \\
\text { SME } \\
\text { delisting }\end{array}$ & $\begin{array}{l}\text { Rating of } \\
\text { larger } \\
\text { company } \\
\text { delisting }\end{array}$ & $\begin{array}{l}\text { Rating of } \\
\text { SME } \\
\text { delisting }\end{array}$ \\
\hline Automobiles and parts & $22.22 \%$ & $70.59 \%$ & $25.00 \%$ & $60.00 \%$ & $0.00 \%$ & $0.00 \%$ & $25.00 \%$ & $60.00 \%$ \\
\hline Construction and materials & $40.54 \%$ & $69.64 \%$ & $75.00 \%$ & $83.33 \%$ & $0.00 \%$ & $0.00 \%$ & $55.56 \%$ & $70.97 \%$ \\
\hline Electronic and electrical equipment & $50.00 \%$ & $45.24 \%$ & $66.67 \%$ & $86.36 \%$ & $0.00 \%$ & $0.00 \%$ & $60.00 \%$ & $75.00 \%$ \\
\hline General industrials & $50.00 \%$ & $61.33 \%$ & $87.04 \%$ & $75.00 \%$ & $0.00 \%$ & $0.00 \%$ & $68.18 \%$ & $74.58 \%$ \\
\hline Healthcare equipment and service & $15.79 \%$ & $47.62 \%$ & $40.00 \%$ & $20.00 \%$ & $0.00 \%$ & $0.00 \%$ & $100.00 \%$ & $80.00 \%$ \\
\hline Household goods and home construction & $100.00 \%$ & $40.00 \%$ & $60.00 \%$ & $50.00 \%$ & $0.00 \%$ & $0.00 \%$ & $0.00 \%$ & $57.14 \%$ \\
\hline Industrial engineering & $36.36 \%$ & $53.23 \%$ & $75.00 \%$ & $90.00 \%$ & $0.00 \%$ & $50.00 \%$ & $75.00 \%$ & $90.00 \%$ \\
\hline Personal goods & $64.29 \%$ & $77.27 \%$ & $66.67 \%$ & $16.67 \%$ & $0.00 \%$ & $0.00 \%$ & $54.55 \%$ & $12.50 \%$ \\
\hline Technology hardware and equipment & $25.00 \%$ & $52.94 \%$ & $76.19 \%$ & $100.00 \%$ & $0.00 \%$ & $0.00 \%$ & $23.08 \%$ & $52.94 \%$ \\
\hline
\end{tabular}

goods in the US, there are few larger companies in these sectors. various locations of operation, especially if they are large, 
visible, and active in countries with different norms and standards than their home country.

It is believed that delisting ratios are influenced by the number of firms, regardless of whether they are suppliers in the global supply chain. Some firms request that their suppliers behave virtuously. ${ }^{4}$ The results indicate that many firms in Spain and China participate in the GC and use the GRI guidelines, although Japanese SMEs have better financial conditions. However, Western firms provide little to no financial assistance to suppliers to meet their standards. ${ }^{4}$ The results regarding their delisting ratios offer some quantitative explanation for such results.

The topic of sustainable management with respect to suppliers in other countries is important, not only for firms in such countries but also for companies in advanced countries. Nike's global supply chain indeed triggered a global discussion regarding child labor in the 1990s.

However, more research is needed to explain the results explicitly in order to add more information on the reasons for delisting, as well as the situation in other sectors and other countries. Additionally, further explanation regarding the relationship between the GC and internal elements, such as firm governance, is required.

\section{References}

1. The Global Compact and Global Reporting Initiative, Making the Connection: Using the GRI G4 Guidelines to Communicate Progress on the UN Global Compact Principles,

https://www.globalreporting.org/resourcelibrary/UNGCG4-linkage-publication.pdf (Accessed: Nov. 25, 2016)

2. Global Reporting Initiative homepage, https://www.globalreporting.org/information/aboutgri/alliances-and-synergies/Pages/UNGC-andGRI.aspx\%20 (Accessed: Nov. 25, 2016)

3. Kolk, A. (2008). Sustainability, accountability and corporate governance: exploring multinationals' reporting practices, Business Strategy and the Environment, 17(1): $1-15$.

4. Vogel, D. (2005). The Market for Virtue: The Potential and Limits of Corporate Social Responsibility (The Brookings Institution, Washington, DC).

5. Knudsen, J.S. (2011). Company delisting from the UN Global Compact: Limited business demand or domestic governance failure? J. Bus. Ethics, 103: 331-349.

6. Tanimoto, K. (2016). Kigyou to syakai no gabanansukouzou no henka, in Proc. $90^{\text {th }}$ Annual Meeting of the Japan Academy of Business Administration.

7. Negishi, K. (2018). Consideration of Voluntary Codes of Conduct in the Japanese Firms' Corporate Social Responsibility: Focusing on the United Nations Global Compact, Journal of Asian Management Studies, 24.

8. Kolk, A. (2016). The social responsibility of international business: from ethics and the environment to CSR and sustainable development, J. World Bus., 51(1): 23-34. 